\title{
Thyroid Peroxidase Antibodies as a Marker of Iodine Status in Healthy Euthyroid Women in First Trimester of Pregnancy Visiting a Tertiary Care Hospital in Raipur, India
}

\author{
Rachita Nanda ${ }^{1}$, Suprava Patel ${ }^{2}$, Prasant Kumar Nayak ${ }^{3}$, Eli Mohapatra ${ }^{4}$, Sarita Agrawal ${ }^{5}$ \\ 1, 2,4 Department of Biochemistry, All India Institute of Medical Sciences, Raipur, Chhattisgarh, India, \\ 3,5 Department of Obstetrics and Gynaecology, All India Institute of Medical Sciences, Raipur, Chhattisgarh, India.
}

\section{ABSTRACT}

\section{BACKGROUND}

The importance of adequate iodine status in pregnancy is undoubted as its deficiency is associated with adverse pregnancy outcomes for the mother as well as the foetus and neonate. Although median urine iodine concentration can assess iodine status of the population but not at an individual level. The purpose of this study was to assess the nutritional status of iodine and identify its effects on thyroid function during the first trimester of pregnancy.

\section{METHODS}

The study was carried out on 341 euthyroid healthy pregnant women using urine iodine concentration and other parameters of thyroid panel at a tertiary care hospital.

\section{RESULTS}

Median (interquartile range) urine iodine concentration and thyroid stimulating hormone (TSH) were $227.37(161.7,343.86) \mu \mathrm{g} / \mathrm{L}$ and $1.8(1.1,2.7) \mathrm{mIU} / \mathrm{L}$ respectively and Mean \pm SD of free thyroxine and thyroid peroxidase antibodies were $14.53 \pm 2.02 \mathrm{pmol} / \mathrm{L}$ and $38.23 \pm 9.29 \mathrm{kIU} / \mathrm{L}$ respectively. Only thyroid peroxidase antibodies showed significant difference across groups with different iodine status. A positive correlation of urine iodine concentration (UIC) with thyroid peroxidase antibodies was observed $(r=0.137, P=0.011)$. Multiple regression analysis revealed that thyroid peroxidase antibodies can serve as an independent predictor of iodine status in the presence of normal levels of TSH and FT4 ( $\mathrm{t}-3.063, \mathrm{CI} ; 0.880,4.038, \mathrm{P}=$ 0.002).

\section{CONCLUSIONS}

Thyroid peroxidase antibodies progressed positively with increase in urine iodine concentration indicating its role as a marker of iodine nutritional status and for early identification of women who can develop autoimmune thyroiditis resulting in hypothyroidism even prior to elevation of thyroid stimulating hormone levels.

\section{KEY WORDS}

Anti-TPO Ab, Free Thyroxine, Thyroid Stimulating Hormone, Urine Iodine Concentration
Corresponding Author:

Dr. Suprava Patel,

Department of Biochemistry,

All India Institute of Medical

Sciences, Raipur,

Chhattisgarh, India.

E-mail:dr_suprava@yahoo.co.in

DOI: $10.14260 / j e m d s / 2021 / 384$

How to Cite This Article:

Nanda R, Patel S, Nayak PK, et al. Thyroid peroxidase antibodies as a marker of iodine status in healthy euthyroid women in first trimester of pregnancy visiting a tertiary care hospital in Raipur, India. J Evolution Med Dent Sci 2021;10(25):1857-1861, DOI: 10.14260/jemds/2021/384

Submission 19-01-2021,

Peer Review 20-04-2021,

Acceptance 28-04-2021,

Published 21-06-2021.

Copyright (C) 2021 Rachita Nanda et al. This is an open access article distributed under Creative Commons Attribution License [Attribution 4.0 International (CC BY 4.0)] 


\section{BACKGROUND}

The iodine deficiency disorders (IDD) control programme is reaching the target of $>90$ per cent of universal salt iodization. ${ }^{1}$ The requirement of iodine is $150 \mu \mathrm{g}$ per day in adults to $250 \mu \mathrm{g}$ per day in pregnancy and lactation. Iodine is important during pregnancy for the well-being of mother and new-born. Median urinary iodine concentration (UIC) is an indicator of iodine status at population level, though not for individual assessment. ${ }^{2}$ The incidences of hypo and hyperthyroidism have been on the rise following iodization of salt. $^{3}$ Overload of iodine results in Wolff-Chaikoff effect, wherein the thyroid peroxidase enzyme synthesis is altered resulting in affecting thyroglobulin iodination. 4 This effect due to acute increase in iodine is later returned back to normal synthesis of thyroid hormones. Excess iodine may be associated with increased risk of thyroid disorders like chronic autoimmune thyroiditis. ${ }^{5,6,7}$ Animal studies have highlighted the dose dependent increase in iodine to increase autoimmune thyroiditis. ${ }^{8}$

Few proposed mechanisms of iodine induced thyroiditis include increased immunogenicity of thyroglobulin activating an immune process, lethal effect on the thyroid cells as a direct effect as well as stimulation of immune and immune related cells. $^{9}$ Antibodies have been shown to be early diagnostic markers of many diseases, however thyroid antibodies are checked only after thyroid abnormality has set in. ${ }^{10,11}$

Anti-TPO Ab (Anti-TPO), have been used as the biomarkers for conversion from euthyroid dysfunction to thyroid dysfunction. ${ }^{12}$ They can destroy thyrocytes through both immune mediated response as well as oxidative stress. ${ }^{13}$ Anti$\mathrm{TPO} \mathrm{Ab}$ as a primary marker to the iodine status has not been appreciated. We have tried to focus the relation of thyroid antibodies in euthyroid pregnant women to their iodine status. Therefore, the intention of this study was to assess the nutritional status of iodine and identify its effects on thyroid function during the first trimester of pregnancy.

\section{METHODS}

This cross-sectional study was conducted for over a period of 2 years from June 2017 to May 2019 at a tertiary care hospital where the institutional ethics committee approval and written consent from the study participants were obtained before including them in the study. It included healthy pregnant women above 18 years with uncomplicated pregnancy in the first trimester (within 14 completed weeks) attending the outpatient department of Obstetrics and Gynaecology by consecutive recruitment. Exclusion criteria included women with signs and symptoms of thyroid dysfunction, history of intake of anti-thyroid drugs or thyroxine whether in past or present, any chronic diseases, multiple gestations, Thyroid stimulating hormone (TSH) $>10 \mathrm{mIU} / \mathrm{mL}$ or positive thyroid peroxidase antibody (anti-TPO) status indicated by anti-TPO levels > $60 \mathrm{kIU} / \mathrm{L}$.

\section{Sample Collection and Laboratory Methods}

Within the above-mentioned period, consecutive 341 pregnant women from booked antenatal cases were screened.
Fasting venous blood of $5 \mathrm{~mL}$ was collected for analysis of TSH, free thyroxine (FT4) and anti-TPO antibodies by chemiluminescence technique, using Siemens ADVIA Centaur $\mathrm{XP}$ immunoassay analyser. The precision of TSH for within run CV \% and run to run CV \% was (1.93 - 4.69) and (1.2 - 6.64) respectively. For FT4 the within run CV \% ranged from 2.23 3.33 and run to run $\mathrm{CV} \%$ from $2.33-4.00$. The assay range and sensitivity of anti-TPO Ab was $15-1300 \mathrm{U} / \mathrm{mL}$ or kIU / L of within run \% CV (1.3 - 6.8) and run to run CV \% (2.8 - 3.4). The reference range of the biochemical parameter by kit manufacturer TSH, FT4 and anti-TPO antibodies was given as 0.55 - $4.78 \mathrm{mIU} / \mathrm{L}, 11.5$ - 22.7pmol / L and < $60 \mathrm{kIU} / \mathrm{L}$ respectively. Spot urine sample $(5 \mathrm{~mL})$ was collected and stored at $-20^{\circ} \mathrm{C}$ for determination of urinary iodine concentration by the wet digestion method on the basis of Sandell-Kolthoff reaction. ${ }^{2}$ Iodine intake was defined as insufficient, adequate, above requirements and excessive for UIC $(\mu \mathrm{g} / \mathrm{L})<150,150-249,250$ - 499, $\geq 500$, respectively.

\section{Statistical Analysis}

It was done by using IPM SPSS 20 and in MS - Excel 2007. Quantitative variables were expressed as mean and standard deviation and median and interquartile ranges. Qualitative variables were expressed as frequencies and percentages. Correlation analysis (Spearman's) was used for finding the correlation of urine iodine with various thyroid hormones. Regression analysis was used with urine iodine as dependent variable to predict thyroid hormones as biomarkers of iodine status. ANOVA with post-hoc analysis was used to compare the hormone levels across various iodine status.

\section{RESULTS}

A total of 341 women who were in the first trimester of pregnancy with singleton pregnancies were enrolled for this study.

\begin{tabular}{|cc|}
\hline Variables & Mean \pm SD, Frequency (N \%) \\
No. of subjects & 341 \\
Mean age & $25.72 \pm 3.96$ \\
Gestational age at sampling (days) & $63.19 \pm 16.7$ \\
Parity & $175(51.3)$ \\
1 & $131(38.4)$ \\
2 & $34(10)$ \\
3 & $1(0.3)$ \\
Occupation Housewife & $263(77.1)$ \\
Working (service) & $78(22.9)$ \\
Socio - economic status Poor & $82(24)$ \\
Average & $212(62.2)$ \\
Good & $47(13.8)$ \\
Intake of Iodised salt (Yes / No) & $341 / 0$ \\
Family history of thyroid disease (Yes / No) & $71(20.8) / 270(79.2)$ \\
\hline Table 1. General Characteristics of the Study Population \\
\hline
\end{tabular}

General characteristics of study population is listed in Table 1 . The mean age was 25.73 years with standard deviation of 3.96. With a mean gestational age in days of 63.19 \pm 16.7 , almost half (51.3\%) were nulliparous and $44 \%$ primigravida.

Approximately $23 \%$ women were working out of home and $62.2 \%$ had average socio-economic status. All participants gave a history of consuming iodised salt in the food consumed at home. Majority of women (79 \%) had no family history of thyroid disease. 


\begin{tabular}{|c|c|}
\hline Biochemical Parameters & Values \\
\hline TSH $(\mathrm{mIU} / \mathrm{L})$ & $1.8(1.1,2.7)$ \\
\hline FT4 $(\mathrm{pmol} / \mathrm{L})$ & $14.53 \pm 2.02$ \\
\hline Anti-TPO (kIU / L) & $38.23 \pm 9.29$ \\
\hline UIC $(\mu \mathrm{g} / \mathrm{L})$ - Total & $227.37(161.7,343.86)$ \\
\hline \multicolumn{2}{|c|}{ Range n (\%) } \\
\hline$<150(\mu \mathrm{g} / \mathrm{L}) 72(21.1)$ & $109.45(91.07,129.53)$ \\
\hline $\begin{array}{l}150-249(\mu \mathrm{g} / \mathrm{L}) 131(38.41) \\
250-499(\mu \mathrm{g} / \mathrm{L}) 113(33.13)\end{array}$ & $\begin{array}{c}201.60(176.4,226.7) \\
345(301.5,413.2)\end{array}$ \\
\hline$\geq 500(\mu \mathrm{g} / \mathrm{L}) 25(7.33)$ & $577.1(523.1,624.2)$ \\
\hline \multicolumn{2}{|c|}{$\begin{array}{l}\text { Table 2. Biochemical Parameters and Urine Iodine Distribution in } \\
\text { Pregnant Women during the First Trimester of Pregnancy }(N=341)\end{array}$} \\
\hline alues are in Mean $\pm S D$, median (Intel & \\
\hline
\end{tabular}

\begin{tabular}{|c|c|c|c|c|c|}
\hline $\begin{array}{l}\text { Para- } \\
\text { meters }\end{array}$ & $\begin{array}{l}\text { Insufficient } \\
(\mathrm{N}=72)\end{array}$ & $\begin{array}{l}\text { Adequate } \\
(\mathrm{N}=131)\end{array}$ & $\begin{array}{l}\text { Above Adequate } \\
\text { ( } \mathrm{N}=113)\end{array}$ & $\begin{array}{l}\text { Excessive } \\
(\mathrm{N}=25)\end{array}$ & $\begin{array}{c}\mathbf{P} \\
\text { Value }\end{array}$ \\
\hline $\begin{array}{c}\text { TSH } \\
(\mathrm{mIU} / \mathrm{L})\end{array}$ & $\begin{array}{c}1.59 \\
(0.99,2.54)\end{array}$ & $\begin{array}{c}1.9 \\
(1.15,2.74)\end{array}$ & $\begin{array}{c}1.89 \\
(1.15,2.84)\end{array}$ & $\begin{array}{c}1.79 \\
(1.10,2.87)\end{array}$ & 0.311 \\
\hline $\begin{array}{c}\text { FT4 } \\
(\mathrm{pmol} / \mathrm{L})\end{array}$ & $14.16 \pm 2.32$ & $14.67 \pm 1.93$ & $14.42 \pm 1.93$ & $14.29 \pm 1.80$ & 0.812 \\
\hline $\begin{array}{l}\text { Anti - TPO } \\
(\mathrm{kIU} / \mathrm{L})\end{array}$ & $37.8 \pm 8.69 a$ & $36.31 \pm 8.37 \mathrm{~b}, \mathrm{c}$ & $39.76 \pm 10.34$ & $41.8 \pm 8.7$ & $0.011^{*}$ \\
\hline \multicolumn{6}{|c|}{$\begin{array}{l}\text { Table 3. Thyroid Hormone Status across the } \\
\text { Ranges of Urine Iodine Concentration Status }\end{array}$} \\
\hline
\end{tabular}

\begin{tabular}{|c|c|c|c|c|}
\hline & & TSH & FT4 & Anti-TPO \\
\hline \multirow{2}{*}{ FT4 } & Correlation Coefficient & $-.339^{* *}$ & & \\
\hline & Sig. $(2$ - tailed $)$ & .000 & & \\
\hline \multirow{2}{*}{ Anti-TPO } & Correlation Coefficient & $.125^{*}$ & $-.129^{*}$ & \\
\hline & Sig. $(2-$ tailed $)$ & .021 & .017 & \\
\hline Ur Iodine & $\begin{array}{l}\text { Correlation Coefficient } \\
\text { Sig }\{2-\text { tailed) }\end{array}$ & .085 & .016 & $.137^{*}$ \\
\hline & $\begin{array}{l}\text { elation Matrix of UIC } \\
\text { in Healthy Pregnar }\end{array}$ & $\begin{array}{l}\text { nd Thy } \\
\text { Womes }\end{array}$ & $\overline{\text { id Ho }}$ & \\
\hline
\end{tabular}

\begin{tabular}{|c|c|c|c|c|c|c|}
\hline & \multicolumn{2}{|c|}{$\begin{array}{l}\text { Unstandardized } \\
\text { Coefficients }\end{array}$} & \multirow[b]{2}{*}{ t } & \multirow[b]{2}{*}{ Sig. } & \multicolumn{2}{|c|}{$\begin{array}{l}95 \% \text { Confidence } \\
\text { Interval for B }\end{array}$} \\
\hline & B & Std. & & & Lower & Upper \\
\hline (Constant) & 81.705 & 68.187 & 1.198 & .232 & -52.421 & 215.831 \\
\hline TSH & 11.184 & & & & -.255 & \\
\hline FT4 & & 3.780 & & & $\begin{array}{l}-3.039 \\
\end{array}$ & 11.832 \\
\hline Anti - TPO & 2.459 & .803 & 3.063 & .002 & .880 & 4.038 \\
\hline \multicolumn{7}{|c|}{$\begin{array}{c}\text { Table 5. Regression Analysis for Predicting Thyroid Hormones } \\
\text { to Serve as Biomarkers of Iodine Status }\end{array}$} \\
\hline
\end{tabular}

The biochemical parameters and urine iodine distribution of healthy pregnant women depicted in Table 2, shows that the median value of TSH and mean values of FT4 and anti-TPO were within the reference range as mentioned by the manufacturer. About $38 \%$ women were in the adequate UIC range and a similar (33\%) were in the above requirement range. Insufficient iodine intake was seen in $21 \%$ women with UIC $<150 \mu \mathrm{g} / \mathrm{L}$ and only $7.33 \%$ had UIC in the excessive range.

Comparison of TSH, FT4 and anti-TPO antibodies in the four groups according to UIC is described in Table 3. Only antiTPO showed significant difference across groups, i.e., between insufficient and excessive $(\mathrm{P}=0.04)$, adequate with above requirements $(\mathrm{P}=0.004)$ and excessive $(\mathrm{P}=0.003)$.

The correlation matrix of UIC with thyroid hormones in Table 4 shows a positive correlation of UIC with anti-TPO antibodies with no significant correlation with TSH and FT4. A negative correlation of TSH was observed with FT4 and a positive significant correlation with anti-TPO. FT4 was significantly correlated inversely with anti-TPO.

Multiple regression analysis to predict thyroid hormones to serve as biomarkers of iodine status reveals that amongst the three, anti-TPO can serve as an independent predictor of iodine status in the presence of normal levels of TSH and FT4 level ( $\mathrm{t}$ - 3.063, CI; 0.880, 4.038, P = 0.002) (Table 5)

\section{DISCUSSION}

The present study revealed that participants were aware of the importance of iodized salt as it was consumed by everyone irrespective of their socio-economic status or occupation. The pregnant women in the first trimester of pregnancy were relatively young $(25.72 \pm 3.96)$ and this could be the reason of their awareness. Kumar et al. in a recent study in 2017, showed that patients lacked basic knowledge about thyroid disorders, however the participants were all in the middle-aged group. ${ }^{11}$

All the thyroid profile parameters of TSH, FT4 and antiTPO were within the range as per the manufacturer. The healthy women were also screened keeping in mind the antiTPO level $<60 \mathrm{kIU} / \mathrm{L}$. In pregnant women the median TSH level was $1.8 \mathrm{mIu} / \mathrm{L}$ much below the recommended level for pregnant women. ${ }^{14} \mathrm{~A}$ little more than $20 \%$ women were in the insufficient category of iodine status, in fact $40 \%$ women were in above adequate range, indicating very high iodine status in these individuals.

By comparison of TSH and FT4 across the four groups of UIC the status of iodine intake was shown, and there was no change in their levels. However, we observed that anti-TPO increased gradually as the iodine status improved. Studies have shown that thyroid autoimmunity may be related to over sufficient status of iodine which is a well-recognised environmental factor. ${ }^{15,16}$ The mechanisms proposed that excess iodine increases the immunogenicity of thyroglobulin protein, thereby precipitating autoimmune process at both $\mathrm{T}$ and B cell level. The toxic effect of iodine directly affects immune and immune related cells. ${ }^{17,18}$ An observational study in China on pregnant women in early pregnancy noted that the median urinary iodine concentration was more in subclinical hypothyroidism which also had a high level of anti-TPO antibody. ${ }^{19}$

The negative correlation of TSH with FT4 $(\mathrm{P}=0.000)$ during the first trimester is consistent with the physiological changes in human chorionic gonadotrophin (HCG). This was similar to the findings of Aguayo et al. and Rebagliato et al.20,21 $\mathrm{TSH}$ was also positively correlated with anti-TPO $\mathrm{Ab},(\mathrm{P}=$ 0.021), although none of the women had anti-TPO level $>60$ KIU / L. As highlighted by Martinez et al. anti-TPO antibodies were associated to higher TSH levels and as the concentration of anti-TPO increased it was associated with gestational SCH. ${ }^{22}$ Consistent with above theory the FT4 was negatively correlated with anti-TPO antibodies (P = 0.017). We found a positive non-significant correlation of urine iodine with TSH and FT4, but a positive significant correlation with anti-TPO antibodies $(\mathrm{P}=0.11)$. This is probably because majority of these women had adequate or more than adequate UIC, and this could have contributed to the TSH and FT4 levels.

The above adequate and excessive iodine concentration in $40 \%$ of the population may be responsible for the raised antiTPO Ab. High iodine is associated with autoimmune thyroid disease as evident by lymphocytic infiltration into the thyroid gland. ${ }^{23}$ Since UIC is inconsistent in correctly measuring iodine status at an individual level, the other marker which can serve to indicate the iodine status is the level of anti-TPO. The regression analysis shows anti-TPO to be the only thyroid marker that can predict the iodine status, even during a state of anti-TPO levels < $60 \mathrm{KIU} / \mathrm{L}$. Thus all pregnant women must 
be screened for anti-TPO along with TSH in the first trimester of pregnancy to know the status of iodine nutrition.

The limitations of this study is the observational nature and hospital based healthy pregnant women. Random sampling from the community would truly reflect the role of anti-TPO as a marker of iodine status. The UIC was measured by the modified wet digestion method, however because of variability in individual excretion of iodine, adjustment with creatinine is suggested, which was not conducted by our lab. However, the lab is enrolled under the centre for disease control and prevention (CDC) and ensuring the quality of urinary iodine procedures (EQUIP) program that provides quality assurance materials to improve the precision and accuracy of urinary iodine analyses.

\section{CONCLUSIONS}

Anti-TPO has a positive predictive effect for the assessment of iodine nutrition, and so can be used for follow-up for the development of autoimmune thyroid disorders due to environmental effects even before the development of hypothyroidism during the first trimester of pregnancy.

Data sharing statement provided by the authors is available with the full text of this article at jemds.com.

Financial or other competing interests: Authors received grants from Council of Science and Technology vide council letter No 172 / CCOST / 218.

Disclosure forms provided by the authors are available with the full text of this article at jemds.com.

The authors would like to thank Chhattisgarh Council of Science and Technology for sanctioning grants vide council letter No 172 / CCOST / 218.

\section{REFERENCES}

[1] Yadav K, Pandav CS. National iodine deficiency disorders control programme: current status \& future strategy. Indian J Med Res 2018;148(5):503-10.

[2] WHO/UNICE/ICCIDD. Assessment of iodine deficiency disorders and monitoring their elimination. A Guide for Programme Managers 2007. [Accessed 05.07.2020] https://www.who.int/nutrition/publications/micronutr ients / iodine_deficiency.pdf

[3] Leung AM, Braverman LE. Iodine-induced thyroid dysfunction. Curr Opin Endocrinol Diabetes Obes 2012;19(5):414-9.

[4] Markou K, Georgopoulos N, Kyriazopoulou V, et al. Iodineinduce hypothyroidism. Thyroid 2001;11(1):501-10.

[5] Vanderpump MPJ. The epidemiology of thyroid disease. Br Med Bull 2011;99:39-51.

[6] Pedersen IB, Laurberg P, Knudsen N, et al. A population study of the association between thyroid antibodies in serum and abnormalities in thyroid function and structures. Clin Endocrinol (Oxf) 2005;62(6):713-20.

[7] Pederson IB, Laurberg P, Knudsen N, et al. An increased incidence of overt hypothyroidism after iodine fortification of salt in Denmark: a prospective population study. J Clin Endocrinol Metab 2007;92(8):3122-7.
[8] Teng X, Shan Z, Teng W, et al. Experimental study on the effects of chronic iodine excess on thyroid function, structure and autoimmunity in autoimmune-prone NOD.H-2h4 mice. Clin Exp Med 2009;9(1):51-9.

[9] Teng X, Shan Z, Chen Y, et al. More than adequate iodine intake may increase subclinical hypothyroidism and autoimmune thyroiditis: a cross-sectional study based on two Chinese communities with different iodine intake levels. Eur J Endocrinol 2011;164(6):943-50.

[10] Siriwardhana T, Krishna K, Ranganathan V, et al. Significance of Anti-TPO as an early predictive marker in thyroid disease. Autoimmune Diseases 2019;2019:1684074.

[11] Kumar P, Khandelwal D, Mittal S, et al. Knowledge, awareness, practices and adherence to treatment of patients with primary hypothyroidism in Delhi. Indian J Endocrinol Metab 2017;21(3):429-33.

[12] Amouzegar A, Ghaemmaghami Z, Beigy M, et al. Natural course of euthyroidism and clues for early diagnosis of thyroid dysfunction: Tehran thyroid study. Thyroid 2017;27(5):616-25.

[13] Godlewska M, Gawel D, Buckle AM, et al. Thyroid peroxidase revisited-what's new? Horm Metab Res 2019;51(12):765-9.

[14] Alexander EK, Pearce EN, Brent GA, et al. 2017 guidelines of the American Thyroid Association for the diagnosis and Management of Thyroid Disease during pregnancy and the postpartum. Thyroid 2017;27(3):315-89.

[15] Alsayed A, Gad AM, Abdel-Baset H, et al. Excess urinary iodine is associated with autoimmune subclinical hypothyroidism among Egyptian women. Endocr J 2008;55(3):601-5.

[16] Fountoulakis S, Philippou G, Tsatsoulis A. The role of iodine in the evolution of thyroid disease in Greece: from endemic goiter to thyroid autoimmunity. Hormones (Athens, Greece) 2007;6(1):25-35.

[17] Asaduzzaman M, Kamrul-Hasan AB, Aminul-Islam AK, et al. Impact of iodine nutrition status on thyroid autoimmunity in subclinical hypothyroid patients attending a tertiary hospital of Bangladesh. Thyroid Res Pract 2018;15(2):75-9.

[18] Teng X, Shan Z, Chen Y, et al. More than adequate iodine intake may increase subclinical hypothyroidism and autoimmune thyroiditis: a cross- sectional study based on two Chinese communities with different iodine intake levels. Eur J Endocrinol 2011;164(6):943-50.

[19] Wang K, Zhang J, Li F, et al. Urinary iodine in early pregnancy is associated with subclinical hypothyroidism in Tianjin, China: an observational study. BMC Endocr Disord 2017;17(1):10.

[20] Aguayo A, Grau G, Vela A, et al. Urinary iodine and thyroid function in a population of healthy pregnant women in the North of Spain. J Trace Elem Med Biol 2013;27(4):302-6.

[21] Rebagliato M, Murcia M, Espada M, et al. Iodine intake and maternal thyroid function during pregnancy. Epidemiology 2010;21(1):62-9.

[22] Martínez PF, García RA, Galindo DEB, et al. Influence of thyroid peroxidase antibodies on TSH levels of pregnant women and maternal-fetal complications. Endocrinol Diabetes Nutr 2018;65(8):444-50. 
[23] Laurberg P, Cerqueira C, Ovesen L, et al. Iodine intake as a determinant of thyroid disorders in populations. Best Pract Res Clin Endocrinol Metab 2010;24(1):13-27. 